\title{
Geochronology and petrochemistry of Late Cretaceous- (?)Paleogene volcanic sequences from the eastern central Patagonian Cordillera $\left(45^{\circ}-45^{\circ} 40^{\prime} S\right)$
}

\author{
Alain Demant \\ Manuel Suárez \\ Rita De la Cruz
}

Pétrologie Magmatique, Université Paul Cézanne (Aix-Marseille 3), Case Courier 441, 13397 Marseille Cedex 20, France

alain.demant@univ-cezanne.fr

\author{
Servicio Nacional de Geología y Minería, \\ Avenida Santa María 0104, Santiago, Chile \\ msuarez@sernageomin.cl \\ rcruz@sernageomin.cl
}

\begin{abstract}
In the eastern part of the central Patagonian Cordillera (45 $\left.15^{\prime}-45^{\circ} 40^{\prime} \mathrm{S}\right)$, northeast of the town of Coihaique, the chronology of volcanic sequences are documented by detailed field work and twelve new K-Ar dates that have established their Late Cretaceous-(?)Paleogene age. The oldest sequence corresponds to the rhyolitic and rhyodacitic domes of the Casa de Piedra Volcanic Complex, of Campanian age, which were emplaced on volcanic rocks of the Aptian-(?) Albian Divisadero Formation. The plagioclase and two pyroxenes andesitic to dacitic lavas of the El Toro Formation and the basalts from Morro Negro have a similar Maastritchian age. However, dacitic lavas with chemical signature similar to that of EI Toro Formation crop out below the Morro Negro sequence showing that the basalts were the latest erupted lavas. Petrologic and geochemical data are used to characterize the three volcanic episodes. The Casa de Piedra volcanic rocks and the andesitic to dacitic lavas of the El Toro Formation have the mineralogy and geochemical signature of subduction-related magmas: enrichment in light rare earth elements (LREE), highly incompatible elements (Rb, Th, $U$ and K), and strong depletion in Nb-Ta. Basalts from Morro Negro show distinct REE and multi-element patterns. Their geochemical signature is similar to that of the Murta Quaternary basalts, inferred to be related to slab window opening, but distinct from that of the Eocene Balmaceda basalts, more akin to within-plate volcanism.
\end{abstract}

Keywords: Volcanism, Patagonian Andes, Upper Cretaceous, K-Ar ages, Petrochemistry.

\section{RESUMEN}

Geocronología y petroquímica de sucesiones volcánicas del Cretácico Superior-¿Paleógeno? del este de la Cordillera Patagónica oriental (4515' $\left.-45^{\circ} 40^{\prime} S\right)$. En la zona oriental de la Cordillera Patagónica central

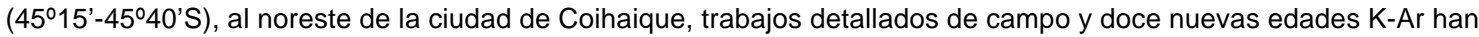
permitido documentar la cronología de las sucesiones volcánicas y establecer su edad del Cretácico Superior¿Paleógeno? La unidad más antigua corresponde a domos riolíticos y riodacíticos del Complejo Volcánico Casa de Piedra, de edad campaniana, que fueron emplazados sobre rocas volcánicas de la Formación Divisadero, del Aptiano-¿Albiano? Las lavas andesíticas a dacíticas de plagioclasa y dos piroxenos de la Formación El Toro y los basaltos de Morro Negro, tienen edades del Maastrichtiano. Sin embargo, lavas dacíticas con una firma química similar a la de la Formación EI Toro afloran topográficamente debajo de los basaltos de Morro Negro, indicando que estas son las lavas más jóvenes de estas tres asociaciones volcánicas. Datos petrológicos y geoquímicos permiten caracterizar los tres episodios 
volcánicos. Las rocas del Complejo Volcánico Casa de Piedra y las andesitas-dacitas de la Formación El Toro tienen la mineralogía y las características geoquímicas de magmas asociados a subducción: fuerte enriquecimiento en Tierras Raras livianas (LREE) y elementos altamente incompatibles (Rb, Th, $\mathrm{U}$ y K), y anomalía negativa en $\mathrm{Nb}$-Ta. Los basaltos de Morro Negro muestran un patrón diferente en los diagramas de Tierras Raras y multi-elementos. Sus características geoquímicas se asemejan a los basaltos cuaternarios de Murta, considerados como relacionados con la apertura de una ventana astenosférica, y los diferencian de las de los basaltos eocenos de Balmaceda, más parecidos a lavas de tipo intraplaca.

Palabras claves: Volcanismo, Andes Patagónicos, Cretácico Superior, Edades K-Ar, Petroquímica.

\section{INTRODUCTION}

The Patagonian Andes (Fig. 1) have registered the complex volcanic and tectonic evolution of the South America continent, affected during the Mesozoic by subduction processes on the Pacific side and the break-up of Gondwana on the Atlantic side. Nowadays, the dominant feature of the geology of northern Patagonia is the subduction-related Mesozoic to Cenozoic Patagonian batholith exposed along the Pacific coast (e.g., Hervé et al. , 2000; Suárez and De la Cruz, 2001). Coeval volcanic activity is more widely represented on the eastern side of the Cordillera (Suárez et al., 1996; Pankhurst et al., 1998, 2003). The Middle-Late Jurassic to Early Cretaceous episode, defined locally as Ibañez Formation (Niemeyer, 1975; Suárez and De la Cruz, 1997; Suárez et al., 1999), corresponds to the emplacement of both andesitic and felsic volcanism. The latter is mostly represented by ignimbrites that are the youngest part of a huge silicic igneous province whose products cover most of Patagonia all the way to the Atlantic coast (Pankhurst and Rapela, 1995; Pankhurst et al., 1998; Féraud et al., 1999; Pankhurst et al., 2000). During the period from Tithonian to Early Aptian the Aysén Basin, a marine back-arc basin representing the northern extension of the oil-bearing Austral Basin (Biddle et al., 1986; Hervé et al., 2000; Suárez et al., 2005a) developed and the Coihaique Group sediments were deposited (e.g., Bell and Suárez, 1997; De la Cruz et al., 2003). During the Late Aptian, as a consequence of the uplift and disappearance of the Aysén Basin, a new major subaerial volcanic episode took place, producing the Divisadero Formation (Heim, 1940; Pankhurst et al., 2003). These Lower Cretaceous rocks were slightly deformed by a weak contractional tectonic event before volcanic activity restarted in Late Cretaceous times (Suárez and De la Cruz, 2000).

Late Cretaceous-(?)Paleogene volcanic rocks have a restricted geographical distribution in the eastcentral Chilean Patagonian Cordillera. The best exposures identified during the mapping program of the Aysén region (De la Cruz et al., 2003; De la Cruz and Suárez, 2006) occur in the area of Coihaique Alto to Baño Nuevo, 20 to $50 \mathrm{~km}$ north-east of the town of Coihaique. In this paper, we presentnew data acquired by the $\mathrm{K}-\mathrm{Ar}$ and ${ }^{40} \mathrm{Ar} /{ }^{39} \mathrm{Ar}$ methods on volcanic rocks from the Late Cretaceous-(?)Paleogene episode that, coupled with previous data (Baker et al., 1981; Butler et al., 1991; Pankhurst et al., 2000, 2003; De la Cruz et al., 2003), will constitute an up to date account of the chronology of the volcanic successions. At the same time, we will detail the petrography, mineralogy and geochemistry of the three defined volcanic episodes, and consider their significance in the framework of the tectonic evolution of the region.

\section{GEOLOGICAL SETTING}

Geological investigations conducted in the Coihaique area during the last decade, have clearly established the stratigraphy of the volcanic successions and the intercalated sedimentary formations (De la Cruz et al., 2003; De la Cruz and Suárez, 2006; Suárez et al., 1996, 2005a, b). During the Tithonian- earliest Cretaceous, a back-arc epicontinental sea covered the area. This marine transgression is represented by the Coihaique Group (Covacevich et al., 1994; Bell and Suárez, 1997; Suárez et al., 1996, 2005a) which comprises from base to top: shallow marine sandstones and oyster beds of the Toqui 
Formation (Suárez and De la Cruz, 1994), black shales of the Katterfeld Formation (Ramos, 1976) and finally, sandstones and shales of the Apeleg Formation (Ploszkiewicz and Ramos, 1977; Bell and Suárez, 1997). The marine Coihaique Group is of major help, when present, for establishing field chronology and distinguishing the Middle Jurassic-Lower Cretaceous
Ibáñez Formation from the Late Aptian Divisadero Formation. The Baño Nuevo Volcanic Complex, contemporaneous with the uppermost Apeleg Formation, corresponds to subaqueous basaltic surtseyan tuff cones that emerged in a shallow marine environment (Suárez et al., 2005b). It crops out east of Ñireguao, in the Baño Nuevo valley.

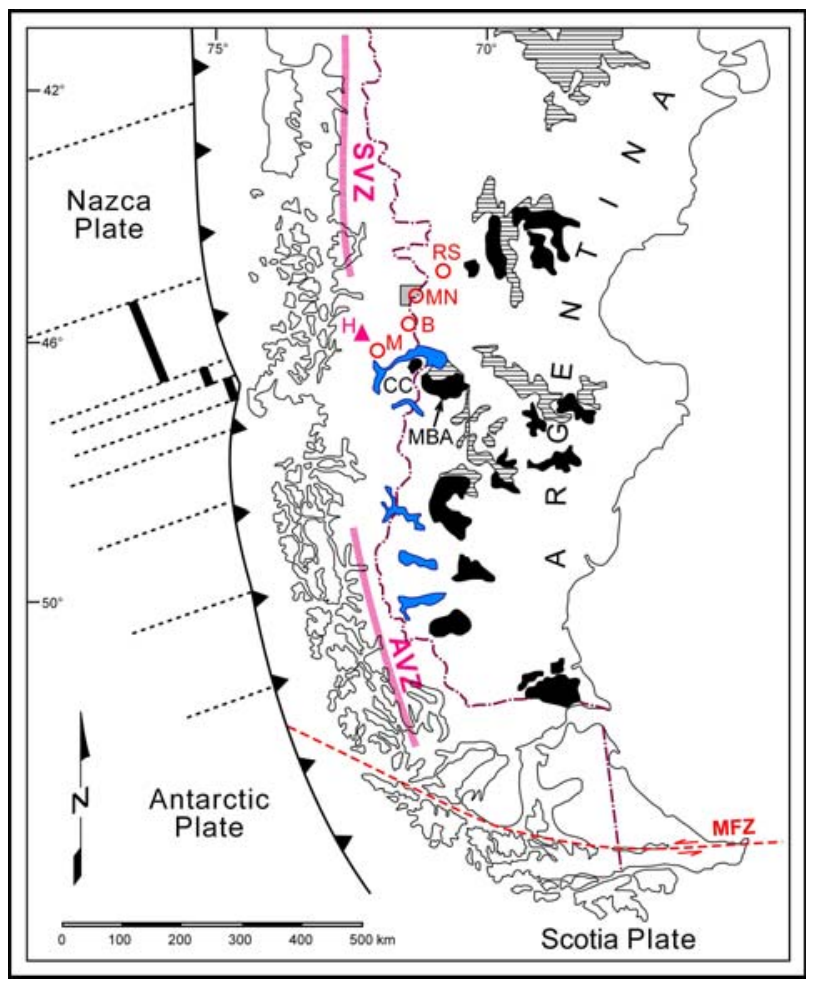

FIG. 1. Schematic geodynamic setting of South America and present day tectonic configuration of Pacific Ocean (adapted from Stern et al., 1990; Kay et al., 1993; Gorring and Kay, 2001; Lagabrielle et al., 2004; D’Orazio et al., 2005). Grey zone near MN: studied area. MN: Morro Negro; RS: Alto Río Senguerr; B: Balmaceda; M: Murta, H: volcán Hudson. Hatched area: Tertiary plateau basalts; black: Quaternary basaltic fields: CC: Chile Chico; MBA: Meseta del lago Buenos Aires. SVZ: Southern volcanic zone of the Andean arc; AVZ: Austral volcanic zone; MFZ: Magallanes fault zone.

This account of the geology of the area is mainly based on geological mapping by the 'Servicio Nacional de Geología y Minería' in the XI Región (Suárez et al., 1996; De la Cruz et al., 2003) together with geochronological, petrological and geochemical data. Three main subaerial volcanic sequences, that rest upon the Divisadero Formation and correspond to the latest Mesozoic-Palaeogene episodes, have been identified in the area of Coihaique Alto. The Casa de Piedra Volcanic Complex (Suárez et al., 1996), crops out mostly along Estero Casa de Piedra and Estero
El Culebra, near the border with Argentina (Fig. 2a). It consists of rhyolitic or rhyodacitic domes, as indicated by rugged shapes and contorted flow bands. The same type of lava is observed below the basalts of Morro Negro. A reconnaissance feature of these lavas is the abundance of quartz phenocrysts visible in hand specimen. Such a concentration of rhyolitic domes is common inside caldera structures after voluminous outpourings of ignimbrites, but in the region of Coihaique Alto no pyroclastic flows of latest Cretaceous age have been documented. 


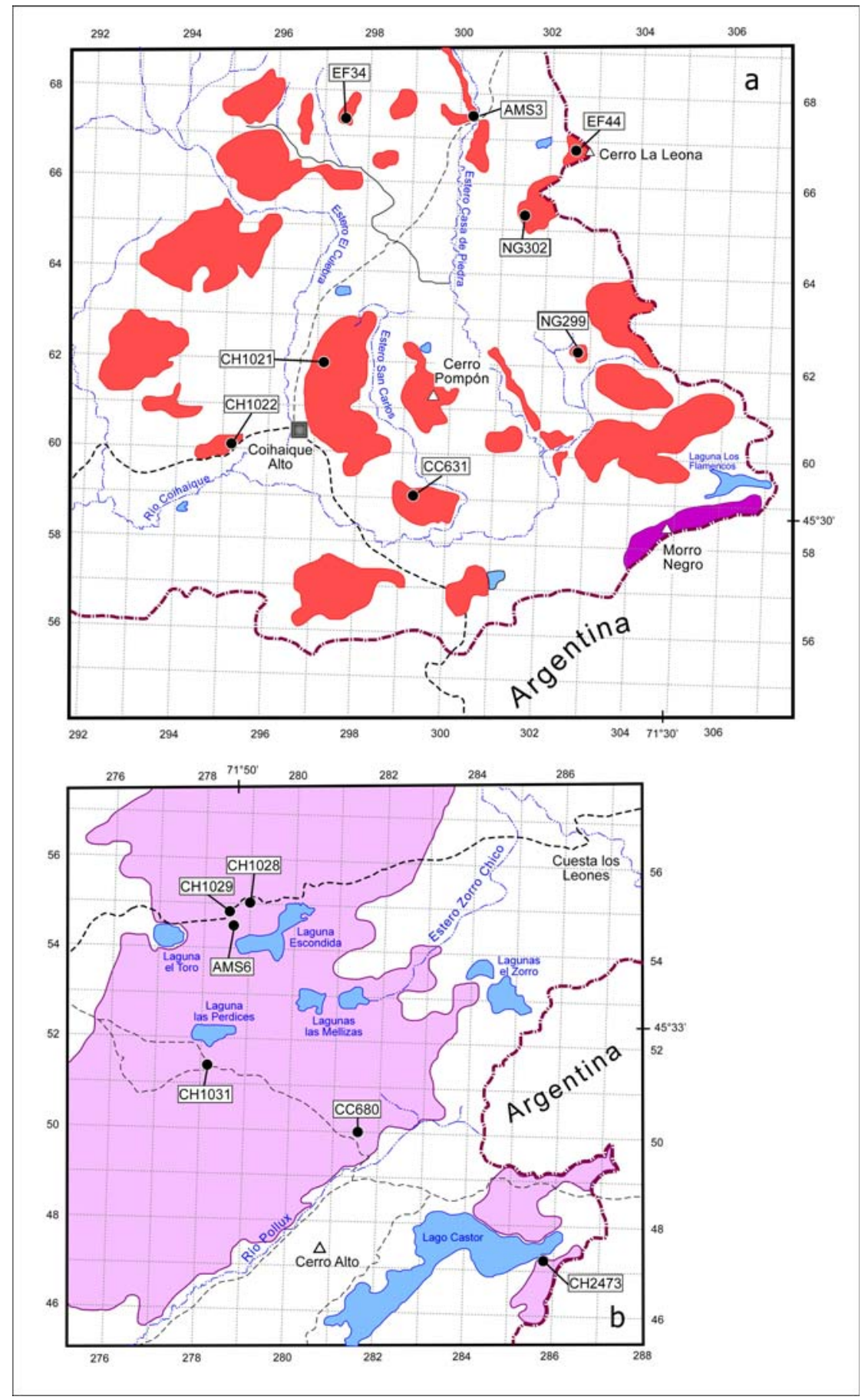

FIG. 2. a. Geological sketch map of the Coihaique Alto region and location of dated samples, modified from the Geological map 1:100.000 Ñireguao-Baño Nuevo (Suárez et al., unpublished); b. sketch map of the Lago Castor area, modified from the Geological map 1:100.000 Coihaique-Balmaceda (De La Cruz et al., 2003).

The ElToro Formation (Dela Cruzetal.,2003)forms extensive exposures midway between Coihaique and Coihaique Alto (Fig. 2b). It is a complex association of andesitic to dacitic lava flows and breccias, reaching up to $450 \mathrm{~m}$ in maximum thickness. A prominent morphological feature is observed on the right side of the 
road running to Coihaique Alto, $1 \mathrm{~km}$ after the entrance of the CONAF 'Monumento Dos Lagunas' preservation area, formed by thick glassy high-silica andesitic lava with complex columnar jointing (Fig. 3). The size and distribution of the prismatic joints is not that of common subaerial lava flows ponded in a valley, which classically exhibit a regular colonnade at the bottom and an irregular upper entablature (Long and Wood, 1986). Fine and irregular columns are observed when lava is rapidly cooled by contact with water, as for example in the case of subglacial lava flows (Dixon et al., 1999). Our interpretation of this thick columnar andesite is that the lava flow ponded in a valley occupied by a lake. The flow progressing beneath the water layer would have developed this spectacular columnar jointing as a result of quenching. Moreover, a related facies of palagonitic lapilli breccias, with some isolated 'cauli- flower' bombs up to $100 \mathrm{~cm}$ in diameter, confirms the occurence of hydromagmatic activity in the region during that period.

The third volcanic sequence corresponds to the basaltic succession observed at Morro Negro, a small meseta close to the frontier with Argentina (Fig. 2b). This basaltic sequence (about $100 \mathrm{~m}$ thick), first studied by Baker et al. (1981), comprises a succession of 17 lava flows (Butler et al., 1991). If the first ones seem to have filled paleovalleys dug into the underlying rhyolitic (Casa de Piedra Volcanic Complex) and andesitic to dacitic (EI Toro Formation) lavas, the latest have the typical flat-lying mesa morphology of the Patagonian Plateau basalts (Fig. 4). Mafic lavas exposed in the area of Alto Río Senguerr, in neighbouring Argentina (Fig. 1, RS), have similar plateau morphology (Baker et al., 1981; Butler et al., 1991).

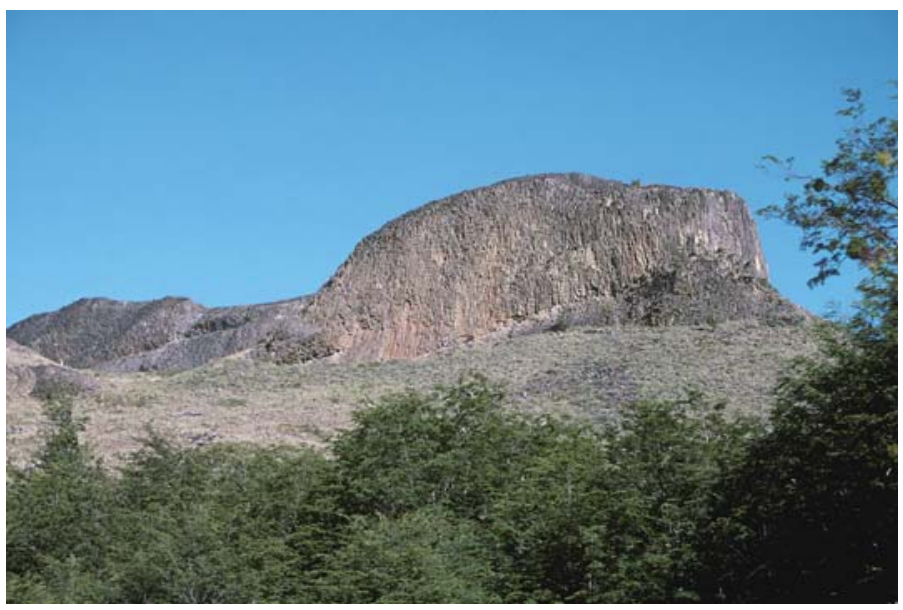

FIG. 3. Prismatic jointing in a lava flow of the EI Toro Formation.

FIG. 4. Basaltic sequence at Morro Negro (see location in figure $2 \mathrm{a}$ ). The smooth hill to the right corresponds to felsic lavas of the Casa de Piedra Volcanic Complex. Note the plateau morphology of the uppermost basaltic lava flows (sample 96-27).

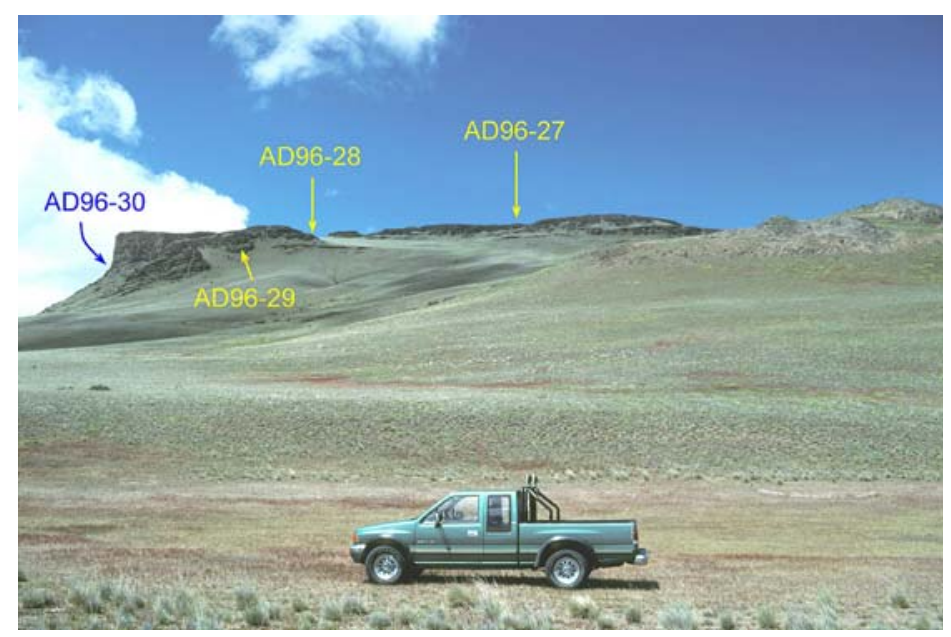


A great part of the area was covered during the Neogene and the Quaternary by thick molassic, glacial and fluvio-glacial deposits accumulated at the eastern foothills of the Andes; moreover, most of the outcrops exhibit clear periglacial features such as sheepback rocks and stone strips.

\section{ANALYTICAL METHODS}

Twelve samples of Late Cretaceous volcanic rocks collected in the eastern central Patagonian Cordillera, were selected for K-Ar dating at the Geochronology Laboratory of the 'Servicio Nacional de Geología y Minería', Chile. Minerals were pretreated and concentrated by standard laboratory techniques and later selected by handpicking under a binocular microscope. For whole-rock analyses, the 60-80 mesh fractions were used. Potassium content was determined by atomic absorption using Lias an internal standard. Argon was extracted in ultra-high vacuum using RFinduction heating and analyzed by the isotope dilution method on an AE1 mass spectrometer. Decay and constants used for calculations are those recommended by Steiger and Jäger (1977).

One sample of the Casa de Piedra Volcanic Complex ( $\mathrm{CH} 1022)$ was also dated by the ${ }^{40} \mathrm{Ar} /{ }^{39} \mathrm{Ar}$ method on biotite by Michael McWilliams at the Stanford University, USA. The sample was wrapped in pure Cu foil and irradiated at the TRIGA reactor at the University of Oregon. Gas was extracted in 15 minute intervals with a double-vacuum (Staudacher-type) resistance furnace with a Ta crucible and replaceable Mo liner. Extracted gas was equilibrated with SAES $\mathrm{Zr}$-Al getters and analyzed in static mode with a MAP 216 mass spectrometer. Dynamic and $1200^{\circ} \mathrm{C}$ static blanks of ${ }^{40} \mathrm{Ar}$ were typically $1 \times 10^{-17}$ and $2 \times 10^{-15} \mathrm{~mol}$, respectively. Isotopic abundances were calculated by linear extrapolation to time zero of peak heights above background during 6-12 serial scans of ${ }^{40} \mathrm{Ar}$ to ${ }^{36} \mathrm{Ar}$. These data were corrected for neutron flux gradients (using sanidine standard 85G003 with an assumed age of $27.92 \mathrm{Ma}$ ), decay since irradiation, mass discrimination, and interference of $\mathrm{Cl}-$, $\mathrm{Ca}$-, and K-pro- duced Ar isotopes. Reported uncertainties are one sigma, determined using uncertainties in monitor age; decay rates of ${ }^{37} \mathrm{Ar},{ }^{39} \mathrm{Ar}$, and ${ }^{40} \mathrm{~K}$; rates of reactor produced Ar isotopes; duration of irradiation; time between irradiation and analysis; peak heights; blank values; and irradiation parameter J. More details on the analytical procedures are given by De la Cruz et al. (2003).

Mineral phases were analyzed on a CAMEBAX microprobe using a wavelength-dispersive spectrometer, at the 'Service microsonde sud' , University of Montpellier, France. The standard operating conditions included an accelerating voltage of $15 \mathrm{kV}$, a beam current of $10 \mathrm{nA}$, and counting times ranging from 20 to $30 \mathrm{~s}$ depending on the analyzed elements.

For the chemical data, eighteen rock samples were ground first in a steel jaw crusher and then finely powdered in an agate grinder. Major and compatible trace elements of samples $A D$ were analyzed by inductively-coupled-plasma-atomic-emission spectrometry (ICP-AES) at the 'Service chimie' CEREGE (Université Paul Cézanne, France) using a Jobin-Yvon system. Na and Rb were determined by flame atomic absorption spectroscopy, and $\mathrm{Fe}^{2+}$ by titration. Rare earth elements (REE) and additional trace elements were obtained by inductively-coupled-plasma-mass spectrometry (ICP-MS) at the University of Montpellier (France). For the other samples, major elements (ICP-AES) and trace elements (ICP-MS) were analyzed at the 'Centre de Recherches Pétrographiques et Géochimiques' (CRPG), Nancy (France). Analytical errors are 1-3\% for major-elements and less than $3 \%$ for trace elements.

\section{GEOCHRONOLOGY}

Analytical data for determination of the K-Ar dates are given in table 1; those for the ${ }^{40} \mathrm{Ar} /{ }^{39} \mathrm{Ar}$ date in table 2. Estimates of the analytical precision are quoted at the 2 s confidence level. The location of the analyzed samples is shown in figures $2 a$ and $2 b$. 
TABLE 1. K-Ar AGE DATA FOR LATE CRETACEOUS-(?)PALEOGENE VOLCANIC SEQUENCES.

\begin{tabular}{|c|c|c|c|c|c|c|c|}
\hline \multirow{2}{*}{ Sample } & \multicolumn{2}{|c|}{ UTM } & \multirow{2}{*}{ Material } & \multirow{2}{*}{$\mathrm{K} \%$} & \multirow{2}{*}{$\begin{array}{c}{ }^{40} \mathrm{Ar} \text { rad. } \\
(\mathrm{nl} / \mathrm{g})\end{array}$} & \multirow{2}{*}{$\begin{array}{c}{ }^{40} \mathrm{Ar} \text { atm. } \\
(\%)\end{array}$} & \multirow{2}{*}{$\begin{array}{c}\text { Age } \\
(\mathrm{Ma} \pm 2 \sigma)\end{array}$} \\
\hline & $\mathrm{N}$ & $\mathbf{E}$ & & & & & \\
\hline \multicolumn{8}{|c|}{ Casa de Piedra Volcanic Complex } \\
\hline CC-631 & 4.959 .055 & 299.919 & Biotite & 6.611 & 21.96 & 16 & $84 \pm 2$ \\
\hline$E F-44$ & 4.966 .830 & 302.500 & Plagioclase & 0.235 & 0.759 & 33 & $81 \pm 4$ \\
\hline NG-299 & 4.962 .403 & 302.711 & Biotite & 6.953 & 22.42 & 25 & $81 \pm 2$ \\
\hline NG-302 & 4.965 .374 & 301.373 & Biotite & 6.973 & 22.31 & 23 & $81 \pm 2$ \\
\hline $\mathrm{CH}-1022$ & 4.959 .987 & 295.257 & Biotite & 7.065 & 22.39 & 16 & $80 \pm 2$ \\
\hline$E F-34$ & 4.967 .320 & 297.500 & Biotite & 6.862 & 21.51 & 20 & $79 \pm 2$ \\
\hline $\mathrm{CH}-1021$ & 4.962 .064 & 296.844 & Whole rock & 2.087 & 6.455 & 13 & $78 \pm 3$ \\
\hline AMS-3 & 4.967 .350 & 300.250 & Biotite & 6.875 & 21.25 & 20 & $78 \pm 2$ \\
\hline \multicolumn{8}{|c|}{ El Toro Formation } \\
\hline $\mathrm{CH}-2473_{(1)}^{(1)}$ & 4.947 .287 & 285.608 & Whole rock & 3.17 & 9.486 & 8 & $75 \pm 2$ \\
\hline $\mathrm{CH}-1031^{(1)}$ & 4.951 .393 & 278.212 & Whole rock & 1.02 & 3.036 & 13 & $75 \pm 3$ \\
\hline $\mathrm{CC}-680^{(1)}$ & 4.949 .906 & 281.474 & Whole rock & 1.08 & 2.819 & 27 & $66 \pm 2$ \\
\hline $\mathrm{CH}-1028^{(1)}$ & 4.954 .940 & 278.844 & Whole rock & 1.68 & 4.329 & 30 & $65 \pm 2$ \\
\hline AMS-6 ${ }^{(1)}$ & 4.954 .225 & 278.725 & Whole rock & 1.52 & 3.784 & 21 & $63 \pm 2$ \\
\hline $\mathrm{CH}-1029^{(1)}$ & 4.954 .858 & 278.685 & Whole rock & 1.46 & 3.140 & 30 & $54,6 \pm 1,9$ \\
\hline NG-473 & 4.971 .161 & 277.565 & Whole rock & 1.185 & 3.63 & 9 & $77 \pm 3$ \\
\hline NG-474 & 4.971 .130 & 277.394 & Whole rock & 1.325 & 3.97 & 8 & $76 \pm 2$ \\
\hline Sample & LAT. & LONG. & Material & $\mathrm{K} \%$ & $\begin{array}{c}{ }^{40} \mathrm{Ar} \text { rad. } \\
(\mathrm{nl} / \mathrm{g})\end{array}$ & $\begin{array}{c}{ }^{40} \mathrm{Ar} \text { atm. } \\
(\%)\end{array}$ & $\begin{array}{c}\text { Age } \\
(\mathrm{Ma} \pm 2 \sigma)\end{array}$ \\
\hline FT-2-5 & $45^{\circ} 03.864$ & $71^{\circ} 01.662$ & Whole rock & 0.92 & 2.17 & 10 & $60 \pm 2$ \\
\hline
\end{tabular}

1 Dates in De La Cruz et al. (2003).

TABLE 2. ${ }^{40} \mathrm{Ar} /{ }^{39} \mathrm{Ar}$ AGE DATA FOR A RHYOLITIC SAMPLE FROM THE CASA DE PIEDRA VOLCANIC COMPLEX.

\begin{tabular}{|ccccccccc|}
\hline Sample & Material & $\begin{array}{c}\text { Total fusion } \\
\text { age } \\
(\mathrm{Ma} \pm 2 \sigma)\end{array}$ & $\begin{array}{c}\text { Plateau } \\
\text { age } \\
(\mathrm{Ma} \pm 2 \sigma)\end{array}$ & $\mathbf{n}_{p} / \mathrm{N}$ & ${ }^{39} \mathrm{Ar} \%$ & $\begin{array}{c}\text { Isochrone } \\
\text { age } \\
(\mathrm{Ma} \pm 2 \sigma)\end{array}$ & MSWD & ${ }^{{ }^{40} \mathrm{Ar} /{ }^{36} \mathrm{Ar}}$ \\
\hline $\mathrm{CH}-1022$ & Biotite & $75.22 \pm 0.74$ & $77.23 \pm 0.76^{*}$ & $4 / 9$ & 41 & $77.80 \pm 1.16$ & 0.69 & $283.3 \pm 14.6$ \\
\hline
\end{tabular}

$\mathrm{n}_{\mathrm{p}} / \mathrm{N}$ : number of steps in the plateau/ total number of steps; ${ }^{39} \mathrm{Ar} \%$ : percentage of total ${ }^{39} \mathrm{Ar}$ released in the plateau; MSWD: 'Mean Square Weighted Deviation' of the inverse isochrone; ${ }^{40} \mathrm{Ar} /{ }^{36} \mathrm{Ar}$ : intercept value ${ }^{40} \mathrm{Ar} /{ }^{36} \mathrm{Ar}$ for the inverse isochrone; ${ }^{*}$ : Preferred age based on the isotopic behaviour.

\section{CASA DE PIEDRA VOLCANIC COMPLEX}

Rhyolitic and rhyodacitic domes are widely exposed north of Coihaique Alto, where they cover an area of about $400 \mathrm{~km}^{2}$ (Fig. 2a). SixnewK-Ardates on biotite give ages ranging from $84 \pm 2$ to $78 \pm 2 \mathrm{Ma}$ (Table 1). Similar ages were obtained on plagioclase from Cerro La Leona, located on the border with Argentina (sample EF-44), and on whole-rock from the dome located north of Coihaique Alto (sample $\mathrm{CH}-1021)$. A more precise ${ }^{40} \mathrm{Ar} /{ }^{39} \mathrm{Ar}$ biotite age of $77.23 \pm 0.76 \mathrm{Ma}$ (Table 2) was obtained from sample $\mathrm{CH}-1022$, which was previously dated by $\mathrm{K}-\mathrm{Ar}$ at $80 \pm 2 \mathrm{Ma}$ (Table 1). An identical whole-rock K-Ar age of 77.3 \pm 2.9 Ma was obtained by Butler et al. (1991) on a dome north of Morro Negro. All the chronological data converge to a Campanian age (Gradstein et al., 2004) for the Casa de Piedra Volcanic Complex.

\section{EL TORO FORMATION}

This subaerial volcanic association, composed of lava flows and subordinate breccias, crops out in the region of the 'Parque Natural Tres Lagunas', about $20 \mathrm{~km}$ ENE of Coihaique. K-Ar analyses were performed on whole-rock samples due to the difficulty in separating plagioclase without glass inclusions. Six samples previously dated by De la Cruz et al. (2003) give two distinct groups of ages (Table 1): one at about $75 \mathrm{Ma}$, the other ranging from $66 \mathrm{Ma}$ to $63 \mathrm{Ma}$. Because aerial volcanic rocks are rapidly cooled, $\mathrm{K}-\mathrm{Ar}$ dates should represent mostly crystallization ages. 
This is in particular the case for the very fresh glassy columnar jointed high-Si andesitic flow (sample AMS6 , Fig. 3) that gives an age of $63 \pm 2 \mathrm{Ma}$ (Table 1 ). Another sample ( $\mathrm{CH} 1028)$ from the same area (Fig. 2b) also gave Maastrichtian age (Gradstein et al., 2004). The 54.6 \pm 1.9 Ma age obtained on an andesite sample near the columnar flow (Fig. 2b, Table 1) seems anomalously young and has probably been reset. The older Campanian ages (75 Ma, Table 1) were obtained on samples located on the southeastern shore of Lago Castor (CH2473), and south of Laguna Las Perdices (CH1031, Fig. 2b). Two additional new whole rock K-Ar ages (samples NG-473, NG-474, not shown on the maps) were performed on andesitic and dacitic lavas from a northern area (18 km NW of Coihaique Alto). They give ages of $77 \pm 3$ and $76 \pm 2$ Ma (Table 1) concordant with the Campanian age reported by De la Cruz etal. (2003). The question that arises when such a large age spectrum is obtained on a volcanic sequence is to know if it really reflects a continuum of the volcanic activity or represents two volcanic events separated by a quiescent period. Be that as it may, the well preserved volcanic features of the prismatic flow (Fig. 3), compared to the other outcrops, is in accordance with its younger age.

\section{MORRO NEGRO BASALTS}

At Morro Negro, 17 lava flows were identified (Butler et al., 1991). Published K-Ar whole-rock dates obtained from the basaltic flows exposed in this small meseta (Fig. 4) range from $75.5 \pm 2.4$ to

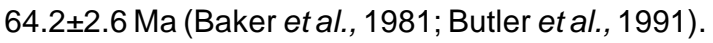
However, as indicated by these authors, the dates do not correlate with stratigraphic position and, moreover, the potassium content and atmospheric Ar of the analyzed samples are highly variable. The analytical errors are high and this could be related to the presence of secondary minerals (zeolites). Morro Negro basalts are the westernmost remnants of a larger basaltic field that crop out in the region of Alto Río Senguerr in Argentina. The same range in ages (from 79.1 to 63.9 $\mathrm{Ma}$ ) and large errors in the dates were obtained on these samples (Butler et al., 1991). The new60 $2 \mathrm{Ma}$ $\mathrm{K}-\mathrm{Ar}$ age (sample FT-2-5, Table 1), obtained on a basaltic lava flow overlying in angular unconformity the Apeleg Formation in Alto Río Senguerr, confirms that basaltic activity in that region extended at least into the Early Tertiary (Danian). Similar large ranges in the duration of mafic volcanic activity are observed in the more prominent and recent plateau basalts of Chile Chico (from 16 to $4 \mathrm{Ma}$, Espinoza et al., 2005) or Meseta del Lago Buenos Aires (from 12 to less than $1 \mathrm{Ma}$; Gorring et al., 2003; Brown et al., 2004; Guivel et al., 2006).

In summary, new and published geochronological data show that the basalts from Morro Negro (Figs. $5 \mathrm{a}, \mathrm{b})$ and the andesitic-dacitic El Toro Formation (Figs. 5c, d) span a large period of time and have been erupted in part synchronously between 77 and $60 \mathrm{Ma}$. Moreover, major columnar jointed hypovolcanic dacitic bodies (i.e., Cerro Mac Kay and Cerro Coihaique) that intrude the Divisadero Formation at the type locality near Coihaique, can also be considered part of the El Toro Formation, as a sample from Cerro Mac Kay provided a wholerock K-Ar age of $63 \pm 2 \mathrm{Ma}$ (De la Cruz et al., 2003).

\section{PETROGRAPHY AND MINERALOGY}

\section{RHYOLITIC AND RHYODACITIC LAVAS OF THE CASA DE PIEDRA VOLCANIC COMPLEX}

Rhyolite from the 'Cueva de las manos' dome, on the eastern side of Estero El Culebra (Fig. 2a) is relatively fresh and can be taken as representative of the mineral composition of these felsic rocks. Rounded to embayed quartz phenocrysts (1 to $3 \mathrm{~mm}$ ) are abundant and associated with relatively well preserved biotite phenocrysts. Felspars are slightly altered and represented mostly by plagioclase phenocrysts; K- feldspars are scarce. The original glassy matrix is devitrified and entirely replaced by a fine grained assemblage of quartz and K-feldspar. Zeolites are also well developed within the devitrified groundmass.

\section{ANDESITIC AND DACITIC LAVAS OF THE EL TORO FORMATION}

The columnar dacite (Fig. 3) is very fresh and representative of the mineral association of the EIToro Formation lavas. These rocks are porphyritic and often 
present a glassy matrix. Two samples have been studied in more detail with the microprobe (Fig. 6). Orthopyroxene and clinopyroxene are the ferromagnesian phases (Table 3 ). Both have relatively homogeneous compositions but orthopyroxene shows a wider range of Mg-content (Fig. 6). Orthopyroxene is found either as phenocrysts or as reaction rims surrounding olivine pseudomorphs heavily altered to phyllosilicates (Fig. 5c). This olivine-orthopyroxene reaction is the result of mixing related to the intrusion of basalt in a shallow andesitic reservoir, a very common mechanism in arc magmatism (Couch et al., 2001; Costa and Singer, 2002; Mortazavi and Sparks, 2004), that frequently triggers the eruptions (Murphy et al., 1998). As a consequence, orthopyroxene surrounding olivine pseudomorphs is slightly more magnesian than the isolated crystals. The orthopyroxeneclinopyroxene pairs in equilibrium with the andesitic melt give an average temperature of $950^{\circ} \mathrm{C}$ (Wells, 1977; Lindsley, 1983). Fe-Ti oxides (titanomagnetite and ilmenite) are present as microcrysts (0.1-0.3 mm).

Plagioclase is very abundant. Some crystals are sieve-textured and contain numerous large glass inclusions, another evidence of disequilibrium (Fig. 5d). Feldspars plot mostly in the andesine to labradorite fields ( $A n_{68}$ to $A n_{38}$; Fig. 6), but high-Ca crystals are also found (up to $A n_{87}$ ). The groundmass is glassy with minute plagioclase crystallites, indicating rapid cooling of the magma at the surface. The light-brown glass has a rhyolitic composition, but relatively low-contents in alkalis.

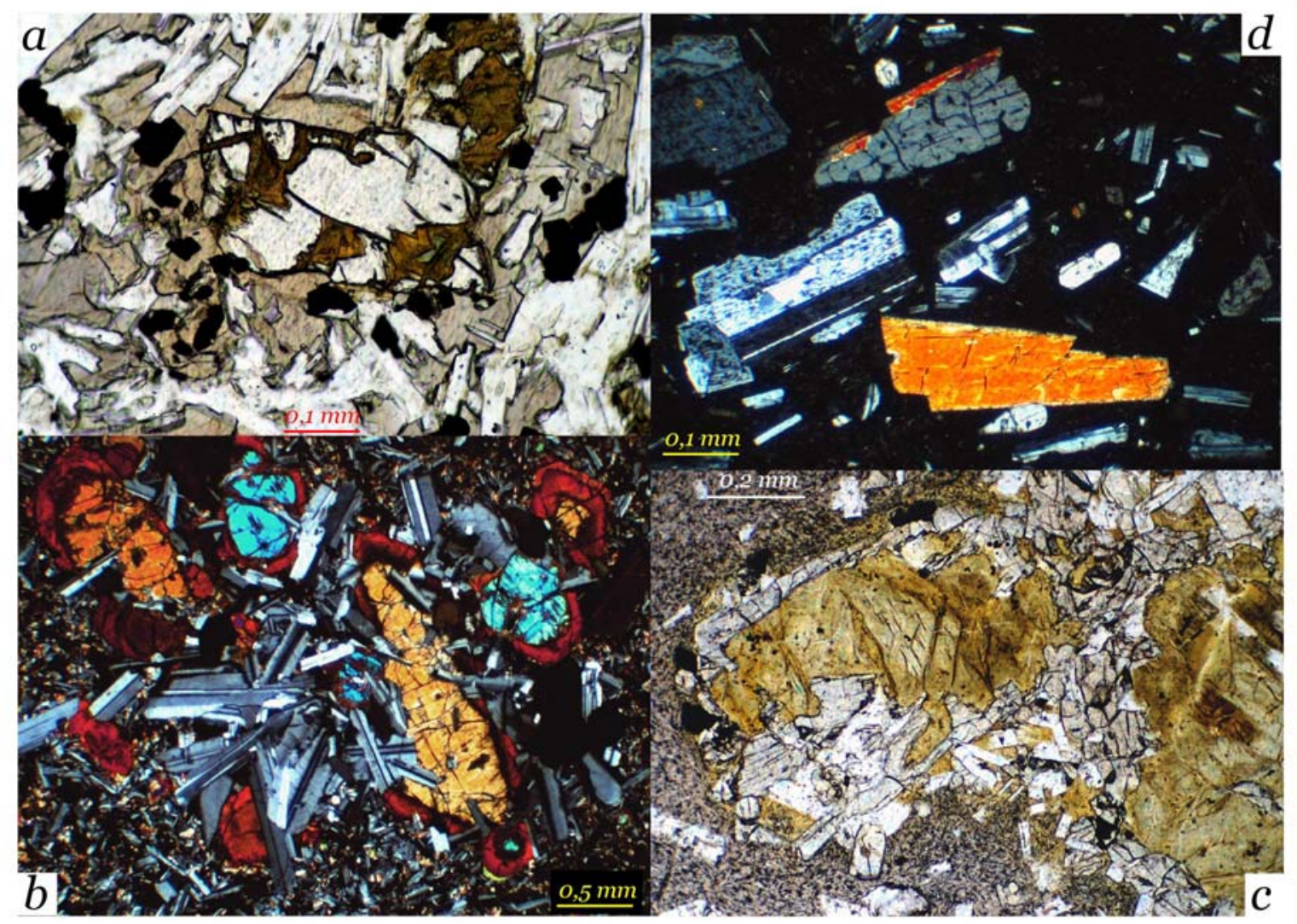

FIG. 5. Microphotographs: a. Subophitic texture in the lowermost flow (AD96-30) of the Morro Negro basaltic sequence; notice that clinopyroxenes have a pinkish color, olivine microphenocryst are partly altered to brownish clay minerals, and Fe-Ti oxides are abundant; b. Glomeroporphyritic assemblage of plagioclase and olivine with iddingsite rim in the Morro Negro mesa basalt (AD9627); c. Olivine phenocrysts altered to brown phyllosilicates and rimmed by orthopyroxene, in the prismatic dacitic lava flow (AD9615); d. Typical assemblage of El Toro Formation dacite (AD96-15): sieve-textured plagioclases, clinopyroxene, and orthopyroxene (grey colored) rimmed by clinopyroxene (orange); phenocrysts are set in a glassy matrix. 


\section{MORRO NEGRO BASALTS}

Basaltic lavas from Morro Negro have a fairly uniform mineral association that comprises plagioclase and olivine phenocrysts set in an intergranular matrix of plagioclase, clinopyroxene and Fe-Ti oxides. The texture of the groundmass varies from fine-grained pilotaxitic (AD96-27), to subophitic (AD96-30) in the thicker lowermost flow (Fig. 5a). A common feature of these basalts is that olivine phenocrysts are rimmed, or entirely altered, to red-brown iddingsite. In the upper mesa lava flow, olivine phenocrysts ( 1 to $2 \mathrm{~mm}$ in size) have compositions in the range $\mathrm{Fo}_{82-80}$ (Table
3); smaller crystals from the matrix have higher Fecontents $\left(\mathrm{Fo}_{60-55}\right)$. Olivine forms glomeroporphyritic assemblages with plagioclase laths (Fig. 5b). Earlyformed small $(<0.1 \mathrm{~mm}$ ) crystals of brown spinel are enclosed within olivine. They have high chromium (28\%-32\%), aluminium (20\%-29\%), and magnesium (7\%-11\%) contents (Fig. 7), and can be referred to as chromian-spinel. Moreover, low $\mathrm{Fe}^{3+}$ contents show that these crystals have not re-equilibrated with the liquid during groundmass crystallization. Inthe lowermost flow, olivine is only present as less magnesian $\left(\mathrm{Fo}_{74}\right.$ ${ }_{64}$; Fig. 7) microcrysts (<0.5 mm), slightly altered to brownish clay minerals (Fig. $5 a)$.

TABLE 3. REPRESENTATIVE MINERAL CHEMISTRY OF EL TORO HIGH-SI ANDESITES AND MORRO NEGRO BASALTS.

\begin{tabular}{|lrrrrrrr|}
\multicolumn{1}{c}{ Basalt AD96-27 } & \multicolumn{1}{c}{ Titanomagnetite } & \multicolumn{2}{c|}{ Ilmenite } & \multicolumn{2}{c|}{ Titanomagnetite } \\
\hline Mineral & Chromite & \multicolumn{2}{c}{ Tite AD96-32 } \\
Analysis & 73 & 77 & 71 & 68 & 69 & 88 & 99 \\
\hline $\mathrm{SiO}_{2}$ & 0.25 & 0.27 & 0.25 & 0.18 & 0.22 & 0.23 & 0.26 \\
$\mathrm{Al}_{2} \mathrm{O}_{3}$ & 29.52 & 20.79 & 1.86 & 0.07 & 0.08 & 1.73 & 2.19 \\
$\mathrm{FeO}$ & 20.43 & 23.23 & 42.87 & 38.30 & 38.22 & 35.93 & 41.20 \\
$\mathrm{Fe}_{2} \mathrm{O}_{3}$ & 13.12 & 13.20 & 21.17 & 9.90 & 9.39 & 55.16 & 42.73 \\
$\mathrm{MnO}$ & 0.29 & 0.35 & 0.55 & 0.61 & 0.45 & 0.18 & 0.10 \\
$\mathrm{MgO}_{\mathrm{TiO}_{2}}$ & 11.07 & 9.21 & 3.61 & 2.74 & 2.69 & 0.32 & 0.75 \\
$\mathrm{Cr}_{2} \mathrm{O}_{3}$ & 1.36 & 3.02 & 18.87 & 48.64 & 48.25 & 5.87 & 12.12 \\
$\mathrm{Total}$ & 23.93 & 29.60 & 10.76 & 0.03 & 0.08 & 0.21 & 0.20 \\
& 99.95 & 99.67 & 99.94 & 100.45 & 99.38 & 99.63 & 99.56 \\
\hline
\end{tabular}

\begin{tabular}{|lrrr|}
\hline Olivine & & & \\
\hline Sample & $\mathbf{9 6 - 2 7}$ & & \\
Analysis & 45 & 52 & 65 \\
\hline $\mathrm{SiO}_{2}$ & 38.83 & 36.19 & 34.97 \\
$\mathrm{Al}_{2} \mathrm{O}_{3}$ & 0.00 & 0.00 & 0.03 \\
$\mathrm{FeO}^{\mathrm{t}}$ & 17.24 & 33.37 & 38.04 \\
$\mathrm{MnO}$ & 0.30 & 0.56 & 0.86 \\
$\mathrm{MgO}$ & 43.39 & 30.59 & 26.36 \\
$\mathrm{CaO}$ & 0.21 & 0.25 & 0.28 \\
$\mathrm{NiO}$ & 0.00 & 0.00 & 0.00 \\
Total & 99.97 & 100.96 & 100.54 \\
Fo & 81.77 & 62.03 & 55.26 \\
\hline
\end{tabular}

\begin{tabular}{|c|c|c|c|c|c|c|c|c|c|c|}
\hline \multicolumn{2}{|c|}{ Plagioclase } & \multirow[t]{2}{*}{ Basalt } & \multicolumn{8}{|c|}{ Dacite } \\
\hline Sample & AD96-27 & & AD96-30 & & & D96-15 & & & & \\
\hline Analysis & 57 & 61 & 304 & 314 & 318 & 254 & 255 & 256 & 259 & 296 \\
\hline $\mathrm{SiO}_{2}$ & 50.40 & 57.16 & 51.88 & 54.31 & 63.16 & 52.94 & 53.69 & 46.12 & 49.96 & 57.49 \\
\hline $\mathrm{Al}_{2} \mathrm{O}_{3}$ & 31.00 & 26.85 & 30.30 & 29.27 & 23.56 & 29.97 & 29.21 & 34.87 & 31.91 & 27.58 \\
\hline $\mathrm{FeO}^{\mathrm{t}}$ & 0.52 & 0.72 & 0.60 & 0.58 & 0.34 & 0.76 & 0.62 & 0.53 & 0.57 & 0.59 \\
\hline $\mathrm{CaO}$ & 14.67 & 9.62 & 13.18 & 11.03 & 4.37 & 12.96 & 12.01 & 18.17 & 15.18 & 9.78 \\
\hline $\mathrm{Na}_{2} \mathrm{O}$ & 3.22 & 6.16 & 3.82 & 4.98 & 7.69 & 4.11 & 4.58 & 1.40 & 2.86 & 5.89 \\
\hline $\mathrm{K}_{2} \mathrm{O}$ & 0.11 & 0.46 & 0.26 & 0.32 & 1.72 & 0.25 & 0.16 & 0.05 & 0.10 & 0.30 \\
\hline Total & 99.92 & 100.98 & 100.03 & 100.48 & 100.84 & 100.98 & 100.27 & 101.14 & 100.58 & 101.62 \\
\hline An & 71.12 & 45.14 & 64.64 & 54.00 & 21.50 & 62.62 & 58.61 & 87.53 & 74.14 & 47.02 \\
\hline$A b$ & 28.28 & 52.27 & 33.86 & 44.13 & 68.44 & 35.95 & 40.44 & 12.20 & 25.28 & 51.25 \\
\hline Or & 0.61 & 2.59 & 1.50 & 1.87 & 10.06 & 1.43 & 0.95 & 0.26 & 0.58 & 1.73 \\
\hline
\end{tabular}

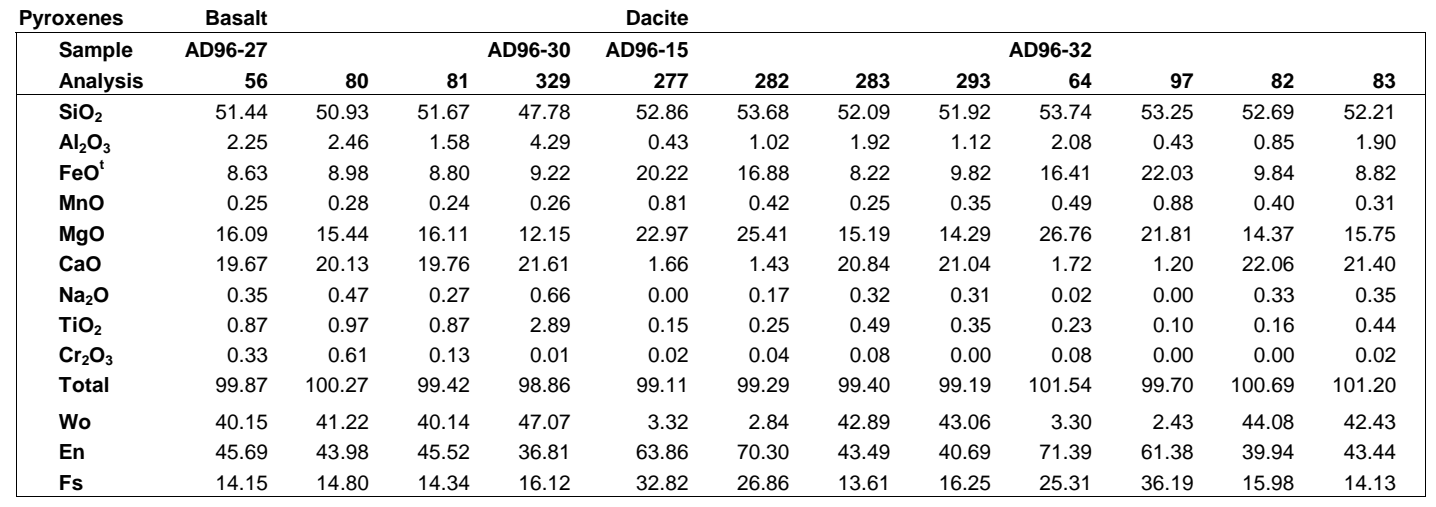


Plagioclase is a major component in all the Morro Negro samples. Plagioclase is mostly labradoritic in composition, with An-contents ranging from $\mathrm{An}_{71}$ to $\mathrm{An}_{44}$ (Fig. 7). In the subophitic lava, late-crystallizing feldspars are oligoclase to anorthoclase in composition $\left(\mathrm{An}_{24-13} \mathrm{Ab}_{68-65} \mathrm{Or}_{8-22}\right)$.

Clinopyroxene is only a groundmass phase, either as minute crystals, or larger crystals incorporating plagioclase blades in the subophitic texture (Fig. $5 b)$. In the first case pyroxene plots in the augite

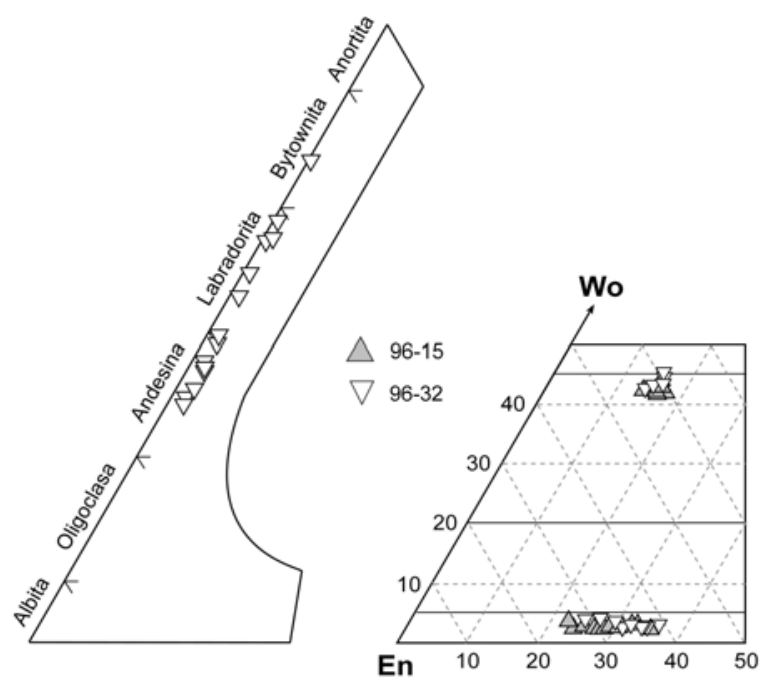

FIG. 6. Mineralogy of two dacites from EI Toro Formation. Sample AD96-15 corresponds to the prismatic lava shown in Figure 3. field $\left(\mathrm{Wo}_{41-35} \mathrm{En}_{44-47} \mathrm{Fs}_{14-18}\right)$, while subophitic pyroxenes have, higher Ca-content (Fig. 7), and plot in the salite field $\left(\mathrm{Wo}_{47} \mathrm{En}_{37} \mathrm{Fs}_{16}\right)$. Their pinkish color (Fig. 5a) reflects higher Ti-contents (Table 3).

Small grains $(\sim 0.1 \mathrm{~mm})$ of Fe-Ti oxides are abundant in the groundmass. The compositions of the coexisting ilmenite and titanomagnetite phases (Table 3), gave equilibration temperatures of about $1.000^{\circ} \mathrm{C}$ (Andersen and Lindsley, 1988), that represent the crystallizing temperature of the matrix.

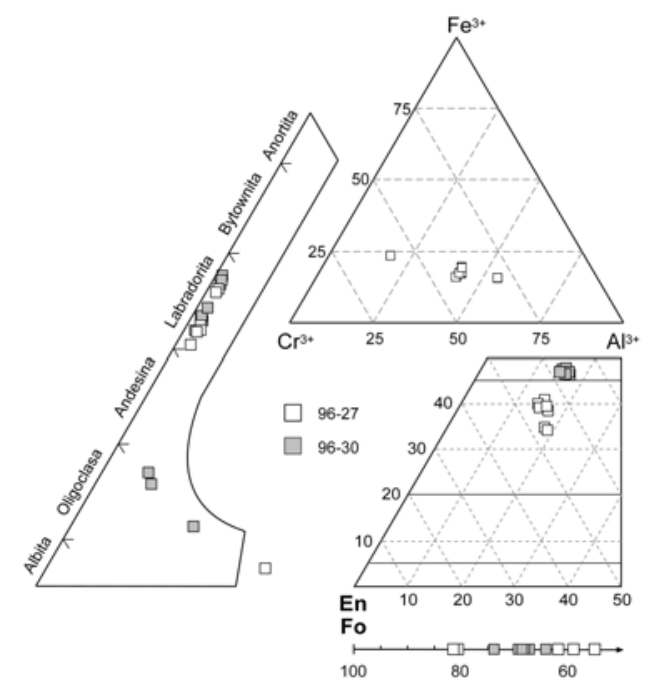

FIG. 7. Mineralogy of two basalts from Morro Negro. Sample AD96-30 corresponds to the lowermost flow and AD96-27 to the upper plateau lavas. Classification diagram of pyroxenes based on Morimoto et al. (1988).

\section{GEOCHEMISTRY}

Eighteen analyses were performed to characterize the chemistry of the Late Cretaceous-Paleogene volcanic sequences from the Coihaique Alto region; they are listed in table 4 . The volcanic sequences are first classified according to the total alkalis vs. silica (TAS) and the $\mathrm{K}_{2} \mathrm{O}$ versus $\mathrm{SiO}_{2}$ diagrams (Fig. 8). In the TAS diagram, the Morro Negro lavas plot in the subalkaline basalt and basaltic andesite fields; lavas from the upper sequence have more silica, but less alkalis and titanium than those of the lower sequence (Table 4). They are therefore quartz normative whereas the older basalts are hypersthene normative. We also show on the TAS diagram the analyses of Morro Negro lavas previously published by Baker et al.
(1981); they plot between the two groups defined by our data set (Fig. 8a). Contemporaneous plateau lavas from Alto Río Senguerr (Baker et al., 1981), have $51-52 \%$ silica, higher alkali contents and hence plot in the mugearite field $\left(\mathrm{Na}_{2} \mathrm{O}-2>\mathrm{K}_{2} \mathrm{O}\right.$; Le Maitre, 1989). The main difference between Morro Negro and Río Senguerr basalts concerns the potassium content, higher in Río Senguerr lavas, as shown on the $\mathrm{K}_{2} \mathrm{O}$ versus $\mathrm{SiO}_{2}$ diagram (Fig. 8b).

The El Toro Formation lavas are mostly high-Si andesites (Table 4), but one sample ( $\mathrm{CH} 1031)$ plots in the basaltic-andesite field and one (CC680) in the dacitic field (Fig. 8a). Finally, all the samples from the Casa de Piedra Volcanic Complex, except one 


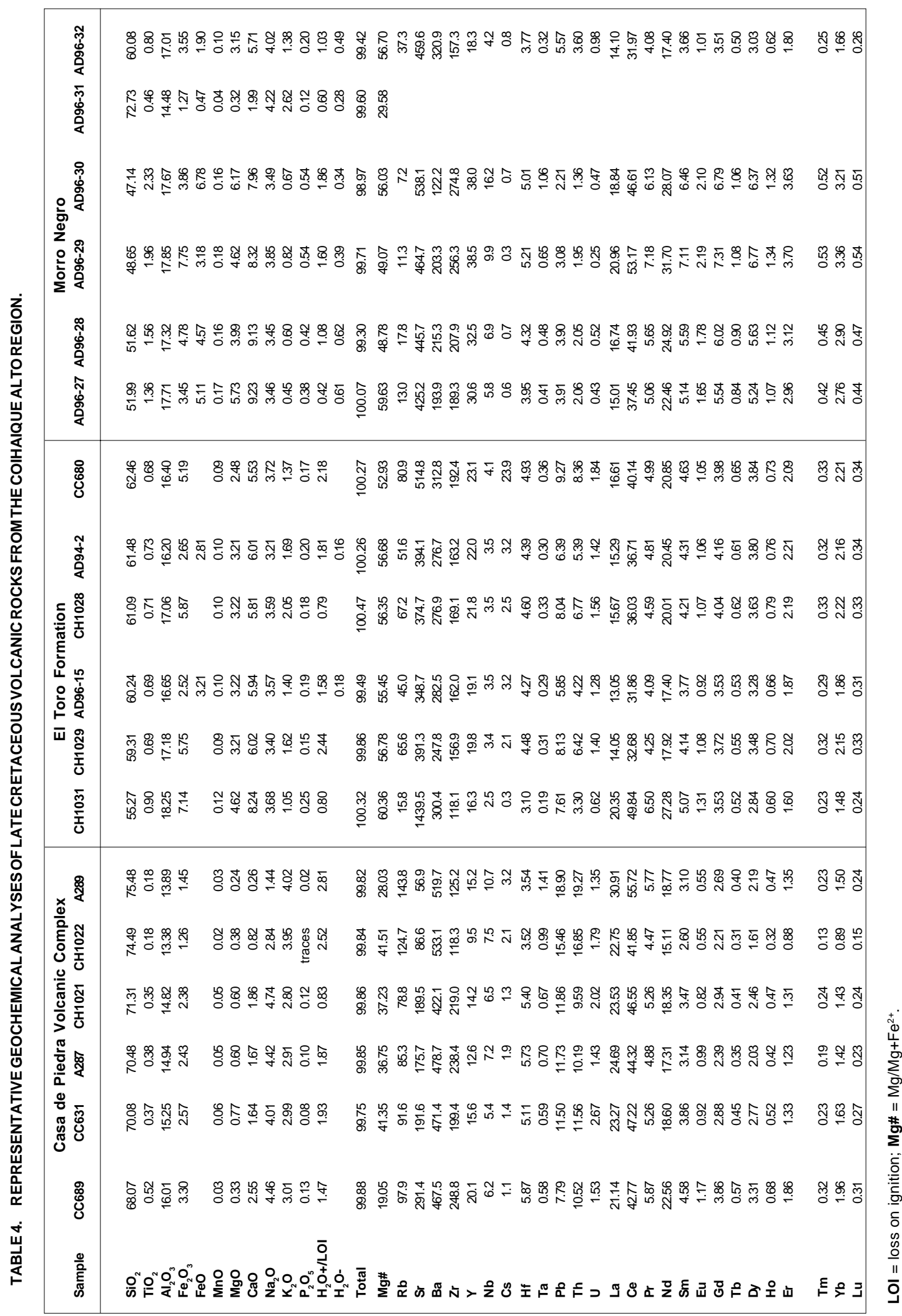


(CC689; Fig. 8a), plot in the rhyolite field. The $\mathrm{K}_{2} \mathrm{O}$ versus $\mathrm{SiO}_{2}$ diagram (Fig. 8b) shows that rocks of the ElToro Formation belong to a medium-K calc-alkaline series, trending towards high-K series for the more evolved rocks. The glassy matrix of sample AD9615 has a chemical composition close to that of these most evolved rhyolites. Rhyolites of the Casa de Piedra Volcanic Complex show a progressive increase in potassium contents (Fig. 8b) but a decrease in total alkalis (Fig. 8a).

\section{MORRO NEGRO BASALTS}

Compatible trace elements $(\mathrm{Ni}<60$ and $\mathrm{Cr}<240$ ppm, Baker et al., 1981) and Mg-numbers $\left[\mathrm{Mg} \#=\right.$ molar $100 * \mathrm{Mg} /\left(\mathrm{Mg}+\mathrm{Fe}^{2+}\right)$, assuming a $\mathrm{Fe}^{3+} /$ $\mathrm{Fe}^{2+}$ ratio of 0.15 ] ranging from 49 to 60 (Table 4) indicate that none of the Morro Negro lavas are primitive liquids. Rare Earth Element (REE) patterns and multielement spider diagrams are classically used to discriminate the basaltic series. Morro Negro basalts display roughly uniform REE patterns (Fig. 9), characterized by a slight enrichment in Light-REE [(La/ $\left.\mathrm{Yb})_{\mathrm{N}}=3.9-4.2\right]$, no major Eu anomaly and $(\mathrm{Lu})_{\mathrm{N}}>$ $(\mathrm{Yb})_{\mathrm{N}}$. On a primitive mantle-normalized diagram (Fig. 10), these basalts show smooth patterns with weak negative anomalies in $\mathrm{Ti}, \mathrm{Pb}$ and $\mathrm{Nb}-\mathrm{Ta}$. The lowermost flow (96-30) does not present negative anomaly in $\mathrm{Nb}-\mathrm{Ta}$.

\section{ANDESITES AND DACITES OF THE EL TORO FORMATION}

Have uniform patterns (Fig. 9), characterized by $(\mathrm{La} / \mathrm{Yb})_{N}$ ratios ranging from 4.7 to 6.0 and a weak negative anomaly in Eu. The range of LREE is about the same as for the basalts, but HREE concentrations are lower. Andesitic sample (55.3\% $\left.\mathrm{SiO}_{2}\right) \mathrm{CH} 1031$ presents a different pattern with higher LREE, no Eu anomaly and lower HREE $\left[(\mathrm{La} / \mathrm{Yb})_{N}=9.9\right]$. The multielement spidergrams are characterized by high concentrations in $\mathrm{Rb}$, Thand $\mathrm{U}$, positive peaks in $\mathrm{K}$ and $\mathrm{Pb}$, weak negative anomalies in $\mathrm{Ba}, \mathrm{P}$ and $\mathrm{Ti}$, a more pronounced depletion in $\mathrm{Nb}-\mathrm{Ta}$ and, finally, low concentrations of the less incompatible trace elements (from Dy to Lu, Fig. 10). Andesite $\mathrm{CH} 1031$ presents a positive peak in $\mathrm{Sr}$ and a stronger $\mathrm{Nb}$-Ta negative anomaly.

\section{RHYOLITES FROM THE CASA DE PIEDRAS VOLCANIC COMPLEX}

Have high concentrations in LREE, an Eu anomaly not always well marked, and a wide range of $\mathrm{HREE}$ $\left[(\mathrm{Lu})_{N}\right.$ from 6 to 12]. Sample CC689 has the lowest LREE/HREE ratio $\left[(\mathrm{La} / \mathrm{Yb})_{\mathrm{N}}=7.7\right]$ and a pattern broadly similar to that of the dacites (Fig. 9), while the other rhyolites have higher LREE but more depleted HREE. The multi-element pattern of rhyolite CC689 is similar to those of the andesites-dacites, with however more pronounced negative anomalies in $\mathrm{P}$ and $\mathrm{Ti}$, and positive peaks in $\mathrm{K}$ and $\mathrm{Pb}$, in relation to their more evolved composition. The other rhyolites are more depleted in all the elements from $\mathrm{Sr}$ to $\mathrm{Lu}$, and more enriched in the highly mobile elements (Fig. 10).

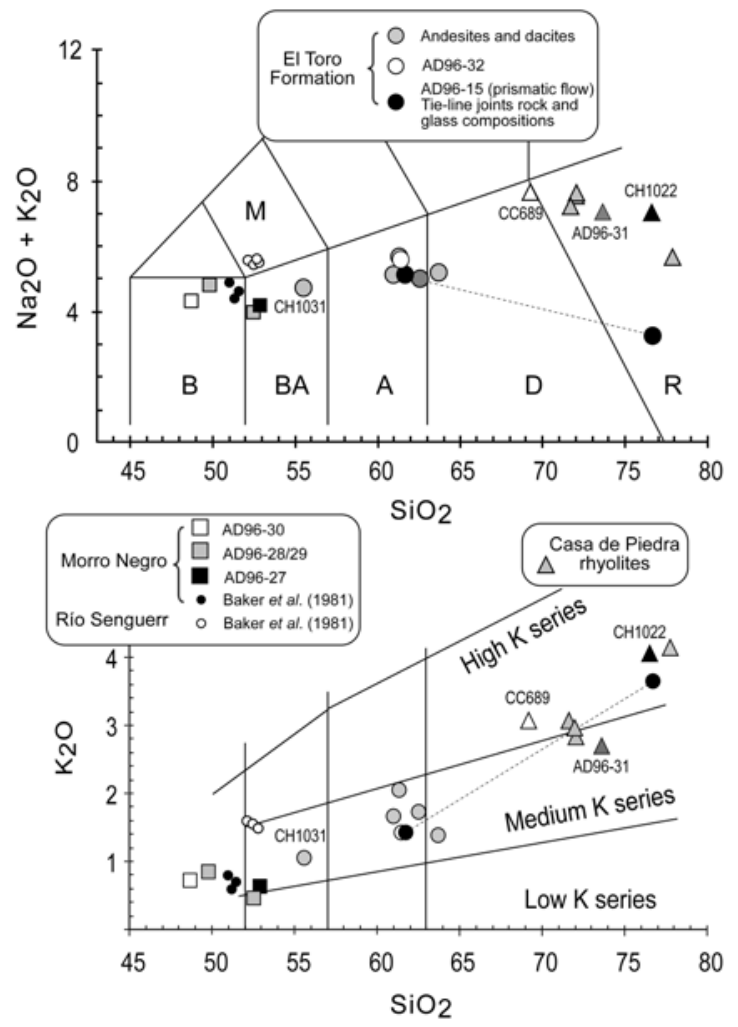

FIG. 8. a. Total alkalis versus $\mathrm{SiO}_{2}$ (TAS, Le Bas et al., 1986) classification diagram for the Late Cretaceous volcanic sequences from Coihaique Alto. B, basalts; BA, basaltic andesite; $A$, andesite; $D$, dacite; $R$, rhyolite; $M$, mugearite b. $\mathrm{K}_{2} \mathrm{O}$ versus $\mathrm{SiO}_{2}$ diagram (Peccerillo and Taylor, 1976). 
In short, whereas the andesitic-dacitic and rhyolitic lavas have typical calc-alkaline affinities (e.g., depletion in $\mathrm{Nb}$ and $\mathrm{Ta}$ ), the Morro Negro basalts have, as first underlined by Baker et al. (1981), geochemical signatures $\left(\mathrm{La} / \mathrm{Nb}\right.$ ratio and $\mathrm{TiO}_{2}$ contents greater than 1, $\mathrm{Al}_{2} \mathrm{O}_{3} \sim 18 \%$ ) intermediate between those of subduction-related magmas and those of within-plate volcanism.

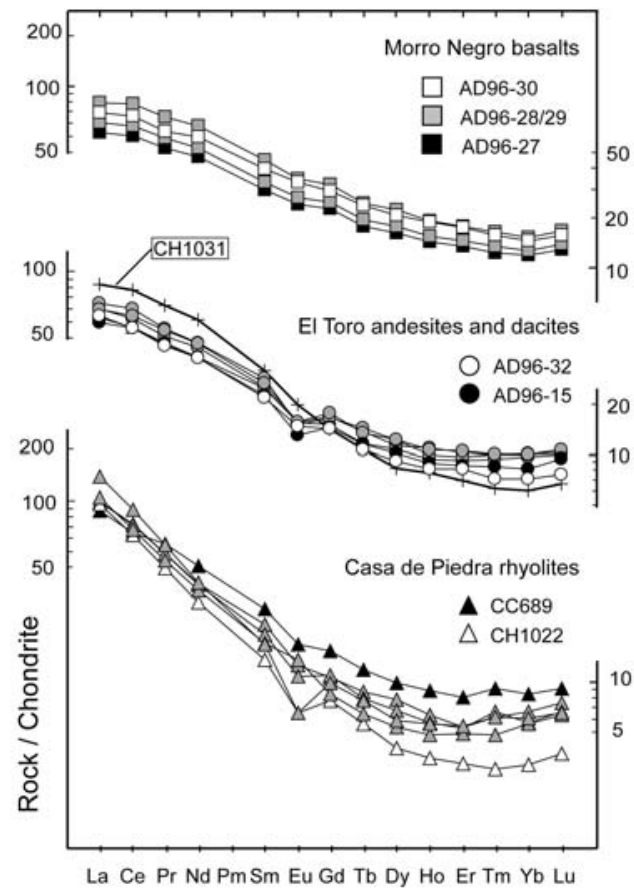

FIG. 9. Rare Earth Element (REE) patterns for the Late Cretaceous volcanic sequences of the Coihaique Alto region. Normalizing values are from Sun and McDonough (1989). Same symbols as in figure 8. Crosses pattern corresponds to adakitic andesite $\mathrm{CH} 1031$. See text for explanations.

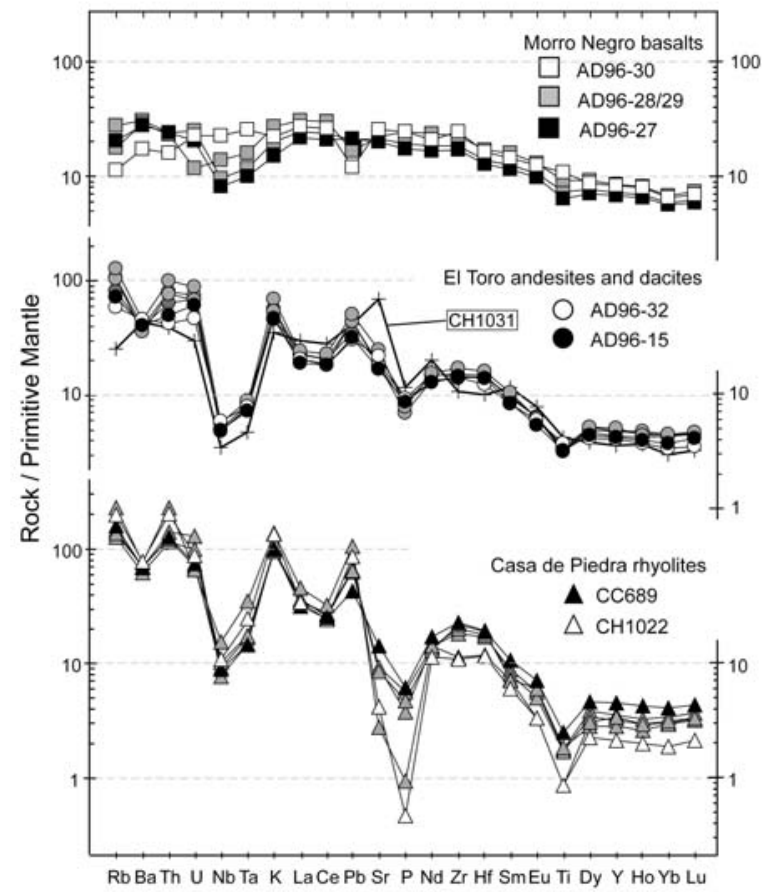

FIG. 10. Multi-element spider diagrams for the Late Cretaceous volcanic sequences of the Coihaique Alto region. Normalizing values are from Sun and McDonough (1989). Same symbols as in figure 8.

\section{DISCUSSION}

The petrochemistry of the Upper Cretaceous andesites-dacites of El Toro Formation shows that they belong tothe subduction-related calc-alkalinevolcanism, and coeval plutonism, active in the Patagonian Cordillera since the Middle Jurassic (Pankhurst etal., 1998, 2000; Suárez and De la Cruz, 2001; Pankhurst et al., 2003). The K-Ar data indicate that basaltic activity (Morro Negro) occurred during an overlapping period of time and may have interfered with the calc-alkaline magmas. The coexistence of different magma types in a single magmatic system is not an unusual feature in arc magmatism (Wallace and Carmichael, 1994;
Petrone et al., 2003). Direct evidence of mixing in dacitic lavas of the EI Toro Formation comes from the presence of ghosts of olivine phenocrysts, of highly calcic plagioclases $\left(A n_{87}\right)$, and high temperatures $\left(950^{\circ} \mathrm{C}\right)$. The influx of hot mafic material in a reservoir located at shallow level in the crust might disturb the magmatic system and cause its rapid emptying. The glassy matrix of some dacites of the EI Toro Formation is consistent with fast ascent and quenching of the magma at the surface after mixing occurred.

Uniform patterns of the dacites in the REE diagram (Fig. 9), buthigher LREE and lower HREE in the andesite 
$\mathrm{CH} 1031$, as well as distinct patterns in the multi-element diagram (Fig. 10), show that the andesite and dacites are not cogenetic. Moreover, the high $\mathrm{Sr} / \mathrm{Y}$ ratio and relatively low concentration of $Y$ evidences the adakitic character of andesite $\mathrm{CH} 1031$ (Defant and Drummond, 1990; Maury et al., 1996; Guivel et al., 1999).

Rhyolites could be the result of fractional crystallization processes or anatexis of the lower crust. $\mathrm{La} / \mathrm{Yb}, \mathrm{Sr} / \mathrm{La}, \mathrm{La} / \mathrm{Nb}$ and $\mathrm{Ba} / \mathrm{Nb}$ ratios show that the Casa de Piedra rhyolites are more akin to evolved rocks of the Andean Southern Volcanic zone or Patagonian Batholith than to melts resulting, like the ignimbrites of the Chon-Aike Province, from the anatexis of the lower crust (Pankhurst and Rapela, 1995). The anomalous abundance of rhyolites in this zone is however not still well understood.

The Upper Cretaceous to lowermost Tertiary basalts of Morro Negro, and their eastern extension in Alto Río Senguerr (Argentina; RS in Fig. 1), constitute the first appearance of plateau lavas in southern Patagonia $\left(44-47^{\circ} \mathrm{S}\right)$. Other occurrences of Early Tertiary back-arc products in the region are, south of Coihaique, the Eocene ( $42 \pm 6 \mathrm{Ma}$ ) Balmaceda basalts (Baker et al., 1981; B in Fig. 1) and, south of Lake General Carrera, the lower basaltic sequence (57-40 Ma) of Meseta Chile Chico (Charrier et al., 1979; Baker et al., 1981; B in Fig. 1; Ramos and Kay, 1992; Espinoza et al., 2005; CC in Fig. 1). Morro Negro basalts have a subduction imprint, as indicated by their depletion in $\mathrm{Nb}$ and $\mathrm{Ta}$. They differ in this aspect from the Eocene Balmaceda basalts (Demant et al., 1996) or the Late Quaternary main plateau basalts from Meseta Chile Chico or Lago Buenos Aires (Gorring et al., 2003; Guivel et al., 2006) which are even more enriched in LILE and LREE elements (Fig. 11b). The clear OIB signature of the latter rocks reflect a deep subslab asthenospheric origin (Ramos and Kay, 1992; Gorring et al., 2003; Espinoza etal., 2005; Guivel et al., 2006). In contrast, Morro Negro basalts share many similarities with the Murta Quaternary basalts (Fig. 11a). These basalts display chemical (Demant et al., 1998) and isotopic features (Guivel et al., 2006) similar to those of oceanic basalts from the Chile Ridge (Klein and Karsten, 1995). These characteristics have been inferred to reflect slab window opening during subduction of segment SCR-1 of the Chile Ridge (Lagabrielle et al., 2004). The geochemical variability of magmatism related to subduction of recent oceanic Ridges and development of slab windows is well documented in southern Chile (Corgne et al., 2001; D'Orazio et al., 2005; Guivel et al., 2006). The signature of Morro Negro lavas can be related to the model recently proposed by Espinoza et al. (2005) that includes the opening, during the Early Tertiary, of a slab window between the Aluk and Farallon plates, to explain the chemical characteristics of the 55-40 Ma lower basaltic sequence at Meseta Chile Chico.

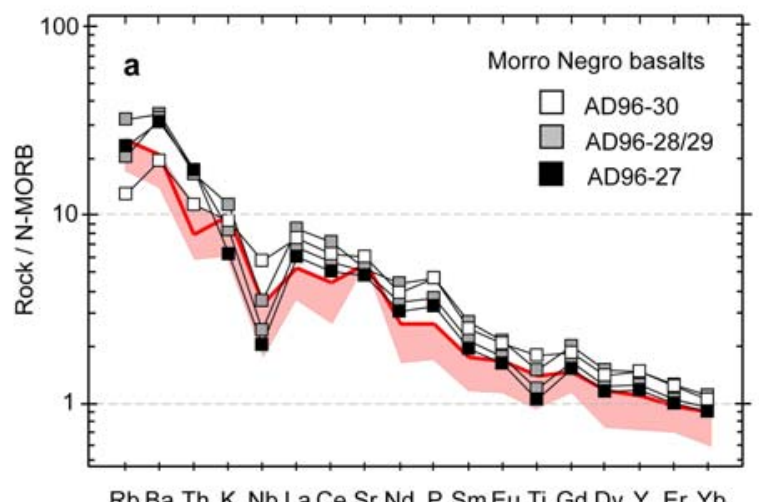

Rb Ba Th K Nb La Ce Sr Nd P SmEu Ti Gd Dy Y Er Yb

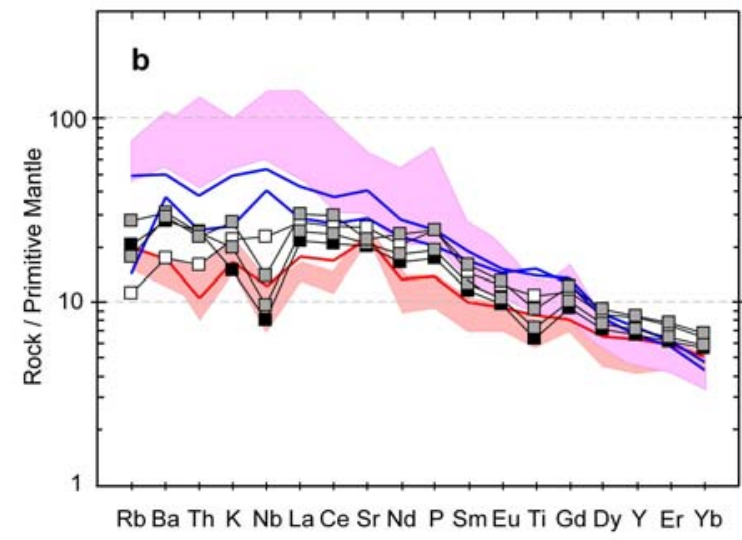

FIG. 11. a. N-Morb normalized multi-element diagrams for Morro Negro and Quaternary Murta basalts. Same symbols as in figure 8. Murta basalt: Heavy red line, analysis in Demant et al. (1998); orange field, analyses in Guivel et al. (2006); b. Primitive mantle normalized multi-element diagrams for Morro Negro and Tertiary to Quaternary Patagonian basalts. Same symbols as in (a); blue lines, Eocene basalts from Balmaceda (Demant et al., 1996); pink field, Plio-Quaternary alkaline post-plateau lavas of Meseta del Lago Buenos Aires with typical OIB signature (Guivel et al., 2006). 


\section{CONCLUSIONS}

Late Cretaceous to Lower Tertiary volcanic rocks are well represented in the area of Coihaique Alto (Aysén region). Three volcanic sequences have been distinguished based on geochronological and petrological data. The oldest sequence corresponds to a number of rhyolitic domes, not related to caldera structures nor to voluminous outpourings of ignimbrites. The mineralogy and chemistry of these rhyolites are those of the calc-alkaline series; they seem more related to fractional crystallization of dacitic magmas, with some participation of contamination with the upper crust, than a result of the anatexis of the lower crust.

Geochronological data have emphasized that dacitic (El Toro Formation) and basaltic activity (Morro
Negro) were in part coeval and that mixing may have occurred favoring the rapid ascent of the calc-alkaline dacitic magmas. Morro Negro basalts have peculiar geochemical signatures. If some kind of subduction imprint is revealed by $\mathrm{Nb}-\mathrm{Ta}$ depletion, the overall geochemistry of these lavas show many similarities with the Quaternary Murta basalts and some Chile Ridge basalts. Such an 'oceanic' signature could be related to the opening of a slab window between the Aluk and Farallon plates. In southern Chile, a progressive change from subduction-related to OIBlike asthenospheric signatures is therefore observed, in the back-arc region, between 70 and $50 \mathrm{Ma}$.

\section{ACKNOWLEGMENTS}

This research was funded by FONDECYT project No. 1030162 and the Servicio Nacional de Geología y Minería, Chile. Our thanks are for Leonardo Zuñiga for friendly collaboration in the field. S.M. Kay (Cornell
University), R.J. Pankhurst (British Geological Survey) and M. Vergara (Universidad de Chile), are sincerely acknowledged for detailed and constructive reviews that contributed to greatly improve the paper.

\section{REFERENCES}

Andersen, D.J.; Lindsley, D.H. 1988. Internally consistent solution models for Fe-Mg-Mn-Ti oxides: Fe-Ti oxides. American Mineralogist 73, 714-726.

Baker, P.E.; Rea, W.J.; Skarmeta, J.; Caminos, R.; Rex, D.C. 1981. Igneous history of the Andean cordillera and Patagonian plateau around latitude $46^{\circ} \mathrm{S}$. Philosophical Transactions of the Royal Society, London A303: 105-149.

Bell, M.C.; Suárez, M. 1997. The Lower Cretaceous Apeleg Formation of the Aisén basin, southern Chile. Tidal sandbar deposits of an epicontinental sea. Revista Geológica de Chile 24 (2): 203-226.

Biddle, K.T.; Uliana, M.A.; Mitchum, R.M.; Fitzgerald, M.G.; Wright, R.C. 1986. The stratigraphic and structural evolution of the central and eastern Magallanes Basin, southern South America. In Foreland basins (Allen, P.A.; Homewood, P.; editors). International Association of Sedimentologists Special Publication 8: 41-61.

Brown, L.L.; Singer, B.S.; Gorring, M.L. 2004. Paleomagnetism and ${ }^{40} \mathrm{Ar} /{ }^{39} \mathrm{Ar}$ chronology of lavas from Meseta del Lago Buenos Aires, Patagonia.
Geochemistry Geophysics Geosystems 5, Q01H04, doi:10.1029/2003GC000526.

Butler, R.F.; Hervé, F.; Munizaga, F.; Beck., M.; Oviedo, E. 1991. Paleomagnetism of the Patagonian Plateau Basalts, southern Chile and Argentina. Journal of Geophysical Research 96: 6023-6034.

Charrier, R.; Linares, E.; Niemeyer, H.; Skarmeta, J. 1979. $\mathrm{K}$-Ar ages of basalt flows of the Meseta Buenos Aires in southern Chile and their relation to the southeast Pacific triple junction. Geology 7: 436-439.

Corgne, A.; Maury, R.C.; Lagabrielle, Y.; Bourgois, J.; Suárez, M.; Cotten, J.; Bellon, H. 2001. La diversité des basaltes de Patagonie à la latitude du point triple du Chili (46-47 lat. S) : données complémentaires et implications sur les conditions de la subduction. Comptes Rendus de l'Académie des Sciences, Paris 333: 363-361.

Costa, F.; Singer, B. 2002. Evolution of Holocene dacite and compositionally zoned magma, Volcán San Pedro, southern volcanic zone, Chile. Journal of Petrology 43: 1571-1593.

Couch, S.; Sparks, R.S.J.; Carroll, M.R. 2001. Mineral 
disequilibrium in lavas explained by convective selfmixing in open magma chambers. Nature 411: $1037-$ 1039.

Covacevich, V.; De la Cruz, R.; Suárez, M. 1994. Primer hallazgo de fauna del Berriasiano Inferior (Neocomiano) en la Formacion Ibañez, Región XI, Aisén. In Congreso Geológico Chileno, No. 8, Actas 1: 425-429. Concepción.

Defant, M.J.; Drummond, M.S. 1990. Derivation of some modern arc magmas by melting of young subducted lithosphere. Nature 347: 662-665.

De la Cruz, R.; Suárez, M.; Belmar, M.; Quiroz, D.; Bell, M. 2003. Geología del área Coihaique-Balmaceda, Región de Aisén del General Carlos Ibáñez del Campo, escala 1:100.000. Servicio Nacional de Geología y Minería, Carta Geológica de Chile, Serie Geología Básica 80: 40 p.

De la Cruz, R.; Suárez, M. 2006. Geología del Área Puerto Guadal-Puerto Sánchez, Región de Aisén del General Carlos Ibáñez del Campo. Servicio Nacional de Geología y Minería, Carta Geológica de Chile, Serie Geología Básica 95: 58 p.

Demant, A.; Hervé, F.; Pankhurst, R.J.; Suárez, M. 1996. Geochemistry of Early Tertiary back-arc basalts from Aysén, southern Chile (44-465.): geodynamic implications. Third International Symposium on Andean Geology (ISAG), St-Malo: 17-19.

Demant, A.; Belmar, M.; Hervé, F.; Pankhurst, R.J.; Suárez, M. 1998. Pétrologie et géochimie des basaltes de Murta : une éruption sous-glaciaire dans les Andes patagoniennes $\left(46^{\circ}\right.$ lat. S.), Chili. Relation avec la subduction de la ride du Chili. Comptes Rendus de l'Académie des Sciences, Paris 327: 795-801.

Dixon, H.J.; Murphy, M.D.; Sparks, R.S.J.; Chávez, R.; Naranjo, J.A.; Dunkley, P.N.; Young, S.R.; Gilbert, J.S.; Pringle, M.R. 1999. The geology of Nevados de Chillán volcano, Chile. Revista Geológica de Chile 26 (2): 227-253.

D'Orazio, M.; Innocenti, F.; Manetti, P.; Haller, M.; Di Vincenzo, G.; Tonarini, S. 2005. The Late Pliocene mafic lavas from the Camusú Aike volcanic field $\left(\sim 50^{\circ} \mathrm{S}\right.$, Argentina): evidences for geochemical variability in slab window magmatism. Journal of South American Earth Sciences 18: 107-124.

Espinoza, F.; Morata, D.; Pelleter, E.; Maury, R.C.; Suárez, M.; Lagabrielle, Y.; Polvé, M.; Bellon, H.; Cotten, J.; De la Cruz, R.; Guivel, C. 2005. Petrogenesis of the Eocene and Mio-Pliocene alkaline basaltic magmatism in Meseta Chile Chico, southern Patagonia, Chile: Evidence for the participation of two slab windows. Lithos 82: 315-343.

Féraud, G.; Alric, V.; Fornari, M.; Bertrand H.; Haller, M. 1999. ${ }^{40} \mathrm{Ar} /{ }^{39} \mathrm{Ar}$ dating of the Jurassic volcanic province of Patagonia: migrating magmatism related to Gondwana break-up and subduction. Earth and Planetary Science Letters 172: 83-96.

Gradstein, F.M.; Ogg, J.G.; Smith, A.G. 2004. A Geologic
Time Scale 2004. Cambridge University Press: 589 p.

Gorring, M.L.; Kay, S.M. 2001. Mantle processes and sources of Neogene slab window magmas from Southern Patagonia, Argentina. Journal of Petrology 42: 1067-1094.

Gorring, M.L.; Singer, B.S.; Gowers, J.; Kay, S.M. 2003. Plio-Pleistocene basalts from the Meseta del Lago Buenos Aires, Argentina: evidence for asthenospherelithosphere interactions during slab window magmatism. Chemical Geology 193: 215-235.

Guivel, C.; Lagabrielle, Y.; Bourgois, J.; Maury, R.C.; Fourcade, S.; Martin, H.; Arnaud, N. 1999. New geochemical constraints for the origin of ridgesubduction-related plutonic and volcanic suites from the Chile Triple Junction (Taitao Peninsula and site 862, Leg ODP141 on the Taitao Ridge). Tectonophysics 311: 83-111.

Guivel, C.; Morata, D.; Pelleter, E.; Espinoza, F.; Maury, R.C.; Lagabrielle, Y.; Polvé, M.; Bellon, H.; Cotten, J.; Benoit, M.; Suárez, M.; De la Cruz, R. 2006. Miocene to Late Quaternary Patagonian basalts $\left(46-47^{\circ} \mathrm{S}\right)$ : Geochronometric and geochemical evidence for slab tearing due to active spreading ridge subduction. Journal of Volcanology and Geothermal Research 149: 346-370.

Heim, A. 1940. Geological observations in the Patagonian Cordillera (Preliminary report). Eclogae Geologicae Helvetiae 33: 25-51.

Hervé, F.; Demant, A.; Ramos, V.; Pankhurst, R.J.; Suárez, M. 2000. The Southern Andes. In Tectonic evolution of South America (Cordani, U.G.; Milani, E.J.; Thomaz Filho, A. and Campos, D.A., editors). International Geological Congress, Rio de Janeiro 31, Actas: 605634.

Kay, S.M.; Ramos, V.; Márquez, M. 1993. Evidence in Cerro Pampa volcanic rocks for slab-melting prior to ridge-trench collision in southern South America. Journal of Geology, 110: 703-714.

Kay, S.M.; Ramos, V.A.; Gorring, M.L. 2002. Geochemistry of Eocene plateau basalts related to ridge collision in southern Patagonia. In Congreso Geológico Argentino, No. 15. El Calafate. CD-ROM.

Klein, E.; Karsten, J.L. 1995. Ocean-ridge basalts with convergent-margin affinities from the Chile Ridge. Nature 374: p. 52-57.

Lagabrielle, Y.; Suárez, M.; Rosselló, E.A.; Hérail, G.; Martinod, J.; Régnier, M.; De la Cruz, R. 2004. Neogene to Quaternary tectonic evolution of the Patagonian Andes at the latitude of the Chile triple junction. Tectonophysics 385: 211-241.

Le Bas, M.J.; Le Maitre, R.W.; Streckeisen, A.; Zanettin, B. 1986. A chemical classification of volcanic rocks based on the total alkali-silica diagram. Journal of Petrology 27: 745-750.

Le Maitre, R.W. 1989. A classification of igneous rocks and glossary of terms. Oxford, United Kingdom. Blackwell Scientific Publications: 193 p. London. 
Lindsley, D.H. 1983. Pyroxene thermometry. American Mineralogist 68: 477-493

Long, P.E.; Wood, B.J. 1986. Structures, textures, and cooling histories of Columbia River basalt flows. Geological Society of America Bulletin 97: 11441155.

Maury, R.C.; Sajona, F.G.; Pubellier, M.; Bellon, H.; Defant, M.J. 1996. Fusion de la croûte océanique dans les zones de subduction/collision récentes : l'exemple de Mindanao (Philippines). Bulletin de la Société géologique de France 167 (5): 579-595.

Morimoto, N.; Fabriès, J.; Ferguson, A.; Ginzburg, I.; Roos, M.; Seifert, F.; Zussman, J. 1988. Nomenclature of pyroxenes. Bulletin de Minéralogie 111: 535-550.

Mortazavi, M.; Sparks, R.S.J. 2004. Origin of rhyolite and rhyodacite lavas and associated mafic inclusions of Cape Akrotiri, Santorini: the role of wet basalt in generating calc-alkaline silicic magmas. Contributions to Mineralogy and Petrology 146: 397-413.

Murphy, M.D.; Sparks, R.S.J.; Barclay, J.; Carroll, M.R.; Lejeune, A.M.; Brewer, T.S.; Macdonald, R.; Black, S. 1998. The role of magma mixing in triggering the current eruption of the Soufriere Hills volcano, Montserrat. Geophysical Research Letter 25: 34333436.

Niemeyer, H. 1975. Geología de la región comprendida entre el Lago General Carrera y el río Chacabuco, Provincia de Aisén, Chile. Memoria de Título (Inédito), Universidad de Chile, Departamento de Geología: $309 \mathrm{p}$.

Pankhurst, R.J.; Rapela, C.R. 1995. Production of Jurassic rhyolite by anatexis of the Lower crust of Patagonia. Earth and Planetary Science Letters 134: 23-36.

Pankhurst, R.J.; Leat, P.T.; Sruoga, P.; Rapela, C.R.; Marquez, M.; Storey, M.; Riley, T.R. 1998. The Chon Aike province of Patagonia and related rocks in West Antarctica: A silicic large igneous province. Journal of Volcanology and Geothermal Research 81: 113-136.

Pankhurst, R.J.; Riley, T.R.; Kelley, S.P. 2000. Episodic silicic volcanism in Patagonia and the Antarctic Peninsula: chronology of volcanism associated with the break-up of Gondwana. Journal of Petrology 41: 605-625.

Pankhurst, R.J.; Hervé, F.; Fanning, M.; Suárez, M. 2003. Coeval plutonic and volcanic activity in the Patagonian Andes: the Patagonian Batholith and the Ibáñez and Divisadero formations, Aisén, southern Chile. In Congreso Geológico Chileno; No. 10, Actas, CD-ROM. Concepción.

Peccerillo, A.; Taylor, S.R. 1976. Geochemistry of Eocene calc-alkaline volcanic rocks from the Kastamonu area, northern Turkey. Contributions to Mineralogy and Petrology 58: 63-81.

Petrone, C.M.; Francalanci, L.; Carlson, R.W.; Ferrari, L.; Conticelli, S. 2003. Unusual coexistence of subduction-related and intraplate-type magmatism: $\mathrm{Sr}, \mathrm{Nd}$ and $\mathrm{Pb}$ isotope and trace element data from the magmatism of the San Pedro-Ceboruco graben (Nayarit, Mexico). Chemical Geology 193: 1-24.

Ploszkiewicz, J.V.; Ramos, V. 1977. Estratigrafía y tectónica de la Sierra de Payaniyeu (Provincia del Chubut). Revista de la Asociación Geológica Argentina 32: 209-226.

Ramos, V. 1976. Estratigrafía de Los Lagos La Plata y Fontana, Provincia de Chubut, República Argentina. In Congreso Geológico Chileno, No. 1, Actas: A43A64. Santiago.

Ramos, V.A.; Kay, S.M. 1992. Southern Patagonian plateau basalts and deformation: back-arc testimony of ridge collisions. Tectonophysics 205: 261-282.

Ramos, V.A.; Kay, S.M.; Singer, B.S. 2004. Las adakitas de la Cordillera Patagónica: Nuevas evidencias geoquímicas y geocronológicas. Revista de la Asociación Geológica Argentina 59: 693-706.

Steiger, R.H.; Jäger, E. 1977. Subcommission on geochronology: Convention on the use of decay constants in geo- and cosmochronology. Earth and Planetary Science Letters 36: 359-362.

Stern, C.R.; Frey, F.A.; Futa, K.; Zartman, R.E.; Peng, Z.; Kyser, K.T. 1990. Trace-element and Sr, Nd, Pb, and $\mathrm{O}$ isotopic composition of Pliocene and Quaternary alkali basalts of the Patagonian Plateau lavas of southernmost South America. Contributions to Mineralogy and Petrology 104 (3): 294-308.

Suárez, M.; De la Cruz, R. 1994. Estratigrafía y paleogeografía mesozoica de Aysen nororiental (45$46^{\circ}$ S), Chile. In Congreso Geológico Chileno, No. 6 , Actas 1: 538-542. Concepción.

Suárez, M.; De la Cruz, R. 1997. Edades del Grupo Ibáñez en la parte oriental del Lago General Carrera (46-47 LS), Aysén, Chile. In Congreso Geológico Chileno, No. 8, Actas 2: 1548-1551. Concepción.

Suárez, M.; De la Cruz, R. 2000. Tectonics in the eastern

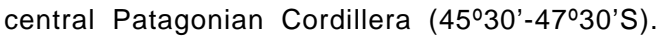
Journal of the Geological Society of London 157: 9951001.

Suárez, M.; De la Cruz, R. 2001. Jurassic to Miocene KAr dates from eastern central Patagonian Cordillera plutons, Chile $\left(45^{\circ}-48^{\circ} \mathrm{S}\right)$. Geological Magazine 138: $53-66$.

Suárez, M.; De la Cruz, R.; Bell, M. 1996. Estratigrafía de la región de Coihaique (latitud $45^{\circ}-46^{\circ} \mathrm{S}$ ); Cordillera Patagónica, Chile. In Congreso Geológico Argentino, No. 13 y Congreso de Exploración de Hidrocarburos. No. 3, Actas 1: 575-590.

Suárez, M.; Demant, A.; De la Cruz, R. 1999. Volcanismo calco-alcalino en W Provincia Chon Aike: Grupo Ibáñez, Jurásico Superior-Cretácico Inferior temprano, Cordillera Patagónica de Aysén, Chile (4530'46³0'S). In Congreso Geológico Argentino, No. 14, Actas 2: 186-189.

Suárez, M.; De la Cruz, R.; Aguirre-Urreta, B.; Fanning, M. 2005a. Diachronic Tithonian-Valanginian marine transgression of the Coihaique Group, Aysén Basin 


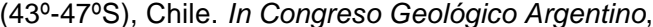
No. 16, Actas 1: 303-304.

Suárez, M.; Demant, A.; De la Cruz, R.; Fanning, M. 2005b. Lower Cretaceous basaltic tuff cones in central Patagonian Cordillera (4520'S), Aysén, Chile. In Congreso Geológico Argentino, No. 16, Actas 1: 305307.

Sun, S.S.; McDonough, W.F. 1989. Chemical and isotopic systematics of oceanic basalts: implications for mantle compositions and process. In Magmatism in the ocean basins (Saunders A.D.; Norry M.J. editors), Geological Society of London Special Publication 42: 313-345. Wallace, P.J.; Carmichael, I.S.E. 1994. Petrology of Volcán Tequila, Jalisco, Mexico: disequilibrium phenocrysts assemblages and evolution of the subvolcanic magma system. Contributions to Mineralogy and Petrology 117: 345-361.

Wells, P.R. 1977. Pyroxene thermometry in simple and complex systems. Contributions to Mineralogy and Petrology 62: 129-139.

Manuscript received: May 10, 2006; accepted: September 29, 2006. 